\title{
Impact of Sez on Rural Economy of Maharashtra
}

\author{
Anant Bapurao Mane ${ }^{* 1}$, Prashant S. Salave ${ }^{2}$ \\ ${ }^{I}$ Research Scholar, Shri jagdish prasad jhabarmal tibrewala university, vidyanagari, Jhunjhunu, Rajasthan - \\ 333001. \\ ${ }^{2}$ Department of Commerce, Shri jagdish prasad jhabarmal tibrewala university, vidyanagari, Jhunjhunu, \\ Rajasthan - 333001 .
}

\begin{abstract}
The case study is based on a survey of households that was carried out in close collaboration with the local community members. Interviews were completed by a consultant acting and a prominent academic and member of the solidarity committee against SEZ. Alongside the quantitative research, extensive personal histories were recorded. The sample of households was made to reflect both those that lost land and those that lost no land, but might otherwise have been indirectly affected. We have used the primary as well as secondary data for conducting the study and analysis of our project work. Primary data mainly composed of the Impact of SEZ on Rural India part, where we have talked with persons from different field and collected their views and information, which helped us a lot to broaden our outlook on the topic.

Keywords: Special Economic Zone (SEZ), local employment, Land ownership, Economic impacts.
\end{abstract}

\section{Introduction}

A Special Economic Zone (SEZ) is a geographical region that has economic laws that are more liberal than a country's typical economic laws. The category 'SEZ' covers abroad range of more specific zone types, including Free Trade Zones (FTZ), Export Processing Zones (EPZ), Free Zones (FZ), Industrial Estates (IE), Free Ports, Urban Enterprise Zones and others. Special Economic Zone (SEZ) is a duty free area which is meant for the purposes of trade operations, duties and tariffs for investors. SEZs are specifically demarcated areas within the country where raw materials and capital goods can be imported duty free from abroad or the domestic market and a special package of tax holiday and incentives are given with a view to boost exports from the country. Manufacturing and Services operations are allowed in a SEZ 1 .

SEZs could be set up in public, private, joint sector or by State governments. The Foreign Trade Policy of Government of India provides for setting up of Special Economic Zones (SEZ) in the country with a view to provide an hassle free environment for exports. Budgets affect all of us. Businesses analyse budget policy in order to make investment decisions that impact on growth and employment. As citizens, we depend on the State to provide crucial services and infrastructure. Whether new roads will be built, whether our children will have schools to go to and whether clinics can adequately cater for the health care needs of the population depends, to a large extent, on the way government raises revenues and allocates money to meet various competing and sometimes conflicting needs ${ }^{2}$.

\section{Methodology}

We have used the primary as well as secondary data for conducting the study and analysis of our project work. Primary data mainly composed of the Impact of SEZ on Rural India part, where we have talked with persons from different field and collected their views and information, which helped us a lot to broaden our outlook on the topic. The opinion of poor people who have lost their land for SEZ has also greatly enhanced our views. Secondary data analysis is commonly known as second-hand analysis. It is simply the analysis of preexisting data in a different way or to answer a different question than originally intended ${ }^{3}$.

For the purpose of study we consulted various: (1) Websites, (2) Search - Engines, (3) Encyclopedia, (4) E Libraries, (5) Articles (published and non-published) written by some of the great research scholars, (6) Journals, News-Papers/E-news-papers, Magazine.

\section{Methodology of the survey}

The case study is based on a survey of households that was carried out in close collaboration with the local community members. Interviews were completed by a consultant acting and a prominent academic and member of the solidarity committee against SEZ. Alongside the quantitative research, extensive personal histories were recorded. The sample of households was made to reflect both those that lost land and those that lost no land, but might otherwise have been indirectly affected.

\section{Description of the survey sample}

The sample for the study covered all habitations of the affected area. 


\section{Land ownership by respondents}

The sample included both households who have lost (some or all) land to the SEZ project and those who did not. Among those who did not lose land there are also households who were landless from the beginning.

\section{Social composition and education of respondents}

The three habitations affected by the SEZ have diverse social composition. Some area has a large number of Backward Castes (lower caste groups), Scheduled Castes (Dalit or "untouchables") and Muslims, as well as some Schedules Tribes and Upper Castes. Backward Castes are numerically the predominant group in the study area. The distribu-tion of respondents by caste is given in Table 3.

\section{Economic impacts}

Losing land to the SEZ project has significantly reduced the farmland in the affected villages and also brought with it severe pressures on employment, livelihoods and food security for the villagers. While some of the land losers have become farmers with smaller land holdings many have become landless. The conversion of farmland for non-farm uses has also reduced farm labour opportunities for the people who had no non-farm skills ${ }^{4}$.

Those who lost land have adopted different approaches to ensure food security and survival depending on their assets, family size and community support. Some have purchased small a few acres from other castes in the village if they had some money or were able to raise loans. Some Lambada households have been able to buy some plot of land from the villagers so that basic survival is not threatened. They bought land at prices far higher than the amount they received for the land acquired for the SEZ. Some of the families are cultivating land on sharing basis where the landowner and the cultivator get equal share in the yield.

\section{Loss of farmland}

The SEZ has caused landlessness among a large section of the households in the affected villages. Land holdings have also become smaller due to SEZ land acquisition. The reduced size of many land holdings has made farming less cost effective. The drastic reduction in the local availability of farmland is also reflected in the decline of leasing. Tenant farmers in the sample have fallen.

\section{Loss of wells and bore wells}

Land acquisition also meant losing wells and bore wells in the lands acquired. Part of the land lost to SEZ was irrigated using wells. In total, several respondents lost wells in the lands taken over by the SEZ (Table 4).

\section{Loss of trees}

Villagers had a variety of trees in the lands that were occupied by the SEZ. Trees provided incomes and food or fruit for the owners, as well as for landless households. Besides, trees are essential for fodder and organic manure. Trees also provide construction materials for housing and have a role in the ritual and belief system of the villagers where for different festivals and pujas specific fruits and leaves are offered. Trees also provide ingredients for medicinal preparations. Every tree has multiple functions and they are important part of rural life (Table 5).

\section{Results And Discussion}

Those who lost land have adopted different approaches to ensure food security and survival depending on their assets, family size and community support. Some have purchased small a few acres from other castes in the village if they had some money or were able to raise loans. Some Lambada households have been able to buy some plot of land from the villagers so that basic survival is not threatened. They bought land at prices far higher than the amount they received for the land acquired for the SEZ. Some of the Lambada families are cultivating land belonging to Polepally on sharing basis where the landowner and the cultivator get equal share in the yield. Several families have one or more members of the family forced to migrate to engage in unskilled jobs in the towns and cities.

A larger number of respondents lost bore wells. Thus the cost of a functional bore well can be estimated at around Rs. 100,000. Despite heavy costs and risks of failing the farmers try several times because it assures one crop at least and also helps achieve three crops if the water yield is good. 
Table 1: Distribution of respondents by habitation

\begin{tabular}{|c|c|c|}
\hline Habitation & Respondents & \% \\
\hline Pune & 23 & 6 \\
\hline Nanded & 43 & 10 \\
\hline Nagpur & 200 & 100 \\
\hline Total & 266 & 100 \\
\hline
\end{tabular}

Table 2: Distribution of respondents in relation to land ownership and loss

\begin{tabular}{|c|c|c|}
\hline Status of land & Respondents & \% \\
\hline Previous landowner that lost land to to SEZ (land loser) & 114 & 60 \\
\hline Landowner with no loss to SEZ & 140 & 30 \\
\hline Landless (from before SEZ) & 12 & 10 \\
\hline Total & 266 & 100 \\
\hline
\end{tabular}

Table 3: Distribution of respondents by caste

\begin{tabular}{|c|c|c|}
\hline Caste & Respondents & \% \\
\hline Backward Castes & 140 & 40 \\
\hline Scheduled Castes & 90 & 15 \\
\hline Schedules Tribes & 16 & 10 \\
\hline Upper Castes & 10 & 15 \\
\hline Muslim & 10 & 10 \\
\hline Total & 266 & 100 \\
\hline
\end{tabular}

Table 4: Loss of wells

\begin{tabular}{|l|l|l|l|l|}
\hline Number of wells owned & Before SEZ & After SEZ \\
\hline & Respondents & \% & Respondents & \% \\
\hline 1 & 20 & 15 & 10 & 12 \\
\hline 2 & 15 & 9 & 4 & 9 \\
\hline 3 & 11 & 7 & 3 & 5 \\
\hline
\end{tabular}

More than half the respondents who lost land have also lost trees of significance. A total of 269 trees were lost by respondents. The loss of trees among the respondents varied by their caste significantly. Scheduled Caste and Backward Caste respondents were the major losers. They constitute $28 \%$ and $23 \%$ respectively of those who lost trees. Upper Caste respondents lost less (Table 5). Scheduled Castes are adversely affected as the tree wealth was a significant support base for them, given their low level of cash savings and land ownership.

Table 5: Respondents who lost trees by caste and species of trees lost.

\begin{tabular}{|c|c|c|c|c|c|c|}
\hline \multirow{2}{*}{$\begin{array}{c}\text { Caste of } \\
\text { respondents }\end{array}$} & \multirow{2}{*}{$\begin{array}{l}\text { Respondents who } \\
\text { lost trees }(\%)\end{array}$} & \multicolumn{5}{|c|}{ Number of respondents who lost trees } \\
\hline & & $\begin{array}{c}\text { Custard } \\
\text { apple } \\
\end{array}$ & Neem & Mango & Other trees & All trees \\
\hline Schedule caste & 28.62 & 6 & 30 & 30 & 11 & 77 \\
\hline Schedule tribe & 20.81 & 3 & 22 & 20 & 13 & 58 \\
\hline Muslim & 15.61 & 3 & 11 & 16 & 12 & 42 \\
\hline Backward caste & 23.79 & 4 & 10 & 40 & 10 & 64 \\
\hline Upper caste & 15 & 3 & 10 & 4 & 11 & 28 \\
\hline Total & 100 & 19 & 84 & 110 & 57 & 269 \\
\hline
\end{tabular}

\section{Summary And Conclusion}

Special Economic Zones are areas specially designated for commercial and supposedly export-oriented activities, under which private companies are able to take advantage of a platter of exemptions from taxation and from national laws on such matters as workers' rights. They are seen as enclaves of quasi-foreign territory and are promoted as a way of attracting foreign direct investment and fostering the growth of export oriented foreign-exchange earning industries. Although they facilitate mainly private and profit-seeking enterprises, they are argued to contribute to "public purpose" through the creation of jobs and, in general, through promoting economic development ${ }^{5}$.

SEZs are, however, highly controversial. Criticisms range from questioning whether they make economic sense for the government and the country, through concerns about environmental impacts, to the negative impacts they have on local communities through displacement. Even within government circles there seems to be a concern that SEZs simply do not make economic sense ${ }^{6}$. 


\section{References}

[1]. Jauch, H. 2002. "Export Processing Zones and the Quest for Sustainable Development: A Southern African Perspective." Environment and Urbanization 14 (1): 101-09.

[2]. Johansson, H., and L. Nilson. 1997. "Export Promoting Zones as Catalyst.” World Development, 25 (12): $2115-28$.

[3]. Ministry of Finance, Govt. of India. 2011. Economic Survey, 2010-11. New Delhi: Ministry of Finance, Govt. of India.

[4]. Mukhopadhyay, P., and Pradhan, K. C. 2009. "Location of SEZs and Policy Benefits: What Does the Data Says?" CPR Occasional Paper No. 18, March. Centre for Policy Research (CPR), New Delhi.

[5]. Mumtaz, Rifat, and Madhumanti Sardar. 2008. "Goa: How the Battle Was Won." InfoChange News and Features. February.

[6]. National Sample Survey Organization (NSSO). 2003. Some Aspects of Operational Land Holdings in India, 2002-03. Report No. 492. New Delhi: Ministry of Statistics \& Programme Implementation, Govt. of India. 